\title{
A homokfásítás alkonya és az ártérfásítás hajnala
}

\section{Tölgyesi Csaba ${ }^{1,2^{*}}$, Bátori Zoltán ${ }^{1}$, Deák Balázs ${ }^{3}$, Erdős László ${ }^{2,4}$, Hábenczyus Alida Anna ${ }^{1}$, Kukla Luca Sára ${ }^{1}$, Török Péter ${ }^{2,5}$, Valkó Orsolya ${ }^{3}$ és Kelemen András ${ }^{5,6}$}

${ }^{1}$ Szegedi Tudományegyetem, Ökológiai Tanszék, 6726 Szeged, Közép fasor 52. ${ }^{2}$ MTA-DE Lendület Funkcionális és Restaurációs Ökológiai Kutatócsoport, 4010 Debrecen, Egyetem tér 1.

${ }^{3}$ Ökológiai Kutatóközpont, Ökológiai és Botanikai Intézet, Lendület Vegetáció és Magbank Dinamikai Kutatócsoport, 2163 Vácrátót, Alkotmány u. 2-4.

${ }^{4}$ Ökológiai Kutatóközpont, Ökológiai és Botanikai Intézet, Kisérletes Vegetációökológiai Kutatócsoport, 2163 Vácrátót, Alkotmány u. 2-4.

${ }^{5}$ Debreceni Egyetem, Ökológiai Tanszék, 4010 Debrecen, Egyetem tér 1.

${ }^{6}$ Horizont Természetvédelmi és Tudományos Egyesület, 4032 Debrecen, Hollós u. 8.

${ }^{*} E$-mail: festuca7@yahoo.com

Összefoglaló: A Duna-Tisza közi homokhátságon az 1970-es évektől jelentős szárazodás figyelhető meg, mely veszélyezteti a térség gazdasági termelékenységét és a vízigényes élőhelyek fennmaradását. Jelenleg nincs konszenzus a szárazodást kiváltó tényezők egymáshoz viszonyított szerepéről. A legellentmondásosabb a homokfásítás kérdése, mely a homoki erdőgazdálkodás nagy múltja miatt „tabunak” számít. Jelen munkánkban a homokhátság erdeinek hidrológiai hatásait tekintjük át, és levezetjük, hogy negatív vízmérleget generálnak, így szárító hatásuk megkérdőjelezhetetlen. Míg több, a szárazodásban közrejátszó tényező szerepe csökkenő tendenciát mutat, a homoki erdőké arányában növekszik, így új erdők telepítése nem ajánlott, sőt, az erdőborítás csökkentése indokolt a letermelésre kerülő faültetvények újratelepítésének mellőzésével. A fásítás súlypontját folyóink ártereibe érdemes áthelyezni, melynek együtt kellene járnia azok kibővítésével, azaz az árterek részleges restaurációjával.

Kulcsszavak: Duna-Tisza közi homokhátság, erdősítés, erdős sztyepp, Kiskunság, szárazodás, talajvízszint-csökkenés, regionális vízháztartás

\section{Bevezetés}

A Duna és Tisza folyók közötti alföldi terület középső, 12000 km²-es sávját a környezeténél 30-70 méterrel magasabb Duna-Tisza közi homokhátság alkotja (1.a ábra). Három megyénk, Pest, Bács-Kiskun és Csongrád-Csanád megye osztozik 

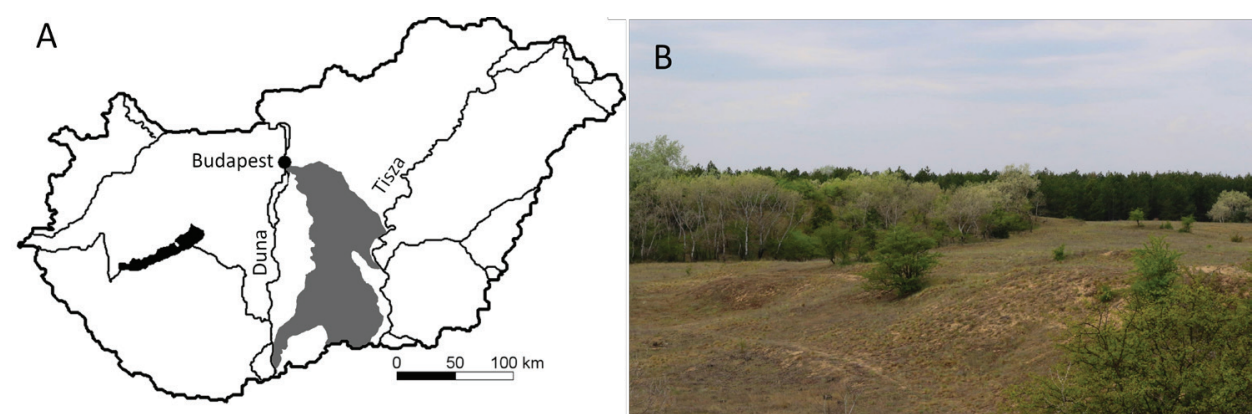

1. ábra. A Duna-Tisza közi homokhátság elhelyezkedése Magyarország területén (a), és a térség természetes, erdős sztyepp jellegü száraz homoki növényzete, mely nyílt homoki gyepekből és cserje-, illetve facsoportokból áll össze (b). A háttérben fenyőültetvény húzódik.

területén, lakossága meghaladja a félmillió fö́t (Szilágyi és Vorosmarty 1997). A Duna-Tisza közi homokhátság nevét adó, durva szemcsés homok alluviális eredetü üledék, melyet az Ös-Duna hagyott hátra a pleisztocén korban, és a későbbiekben eolikus folyamatok alakították ki mai, döntően homokbuckás felszínét (Molnár 2003). A rossz vízgazdálkodású homoktalaj, kombinálva a szubmediterrán hatás alatt álló kontinentális klímával nem tette lehetővé zárt erdők spontán kialakulását. A régió természetes növényzete erdős sztyepp (Erdős et al. 2018), mely erdőfoltok és száraz gyepfoltok mozaikos elrendeződését jelenti (1.b ábra). E növényzeti formáció természetes voltát igazolja a felhagyott erdők fokozatos felnyílása, és az erdős sztyepp fiziognómia kialakulása. Az Ásotthalmi emlékerdő például az erdészeti tevékenységek 1908-as felhagyását követően felnyílásnak indult, és már a szárazodást megelőzően, az 1950-es években is nyílt gyepekkel tarkított facsoportokra tagolódott (Bodrogközy 1957, Gaskó 2009, Erdős et al. 2015). Másik eklatáns bizonyíték a kiterjedt fátlan vegetáció evolúciós időléptékủ jelenlétére a bennszülött gyepi fajok nagy száma, mint például a Colchicum arenarium W. et K., Dianthus diutinus Kit., D. serotinus W. et K. vagy a Tragopogon floccosus W. et $\mathrm{K}$. A régióra jellemző erdős sztyepp tájat néhol deflációs mélyedések tarkítják, ahol a talajvíz közelsége, esetenként felszínre bukkanása kisebb-nagyobb vizes és vízi élőhelyek kialakulását is lehetővé tette (Szilágyi et al. 2012).

E változatos, de szélsőséges környezeti adottságokkal rendelkező régió évszázadok óta az ökológiai problémák tárházának számít. A török hódoltság során és az azt követő időkben az amúgy is gyér erdők jelentős részét letermelték. Egyes beszámolók szerint több tíz kilométert lehetett megtenni úgy, hogy egyetlen fa sem került az utazó szeme elé (Magyar 1961, Erdős et al. 2015). Az őshonos, vagy erdőirtás után másodlagosan kialakult gyepterületeket túllegeltették, mely a talaj erózióját vonta maga után, és így a térség számos pontja nyílt, sivatagokat idéző tájjá alakult. A mozgó homok fenyegette a mezőgazdasági termelést, és 
közegészségügyi problémákat jelentett a szálló por. A probléma orvoslását a kor embere a homokfásításban látta (Magyar 1961), mely nézet az elmúlt 200 évben folyamatosan tartotta magát. A faültetvények valóban megkötötték a homokot, és a homok mozgását kiváltó túlzott mértékü legeltetetés is háttérbe szorult. A 20. század második felére eltűntek a mozgó homokbuckák, a probléma látszólag megoldódott. Ez olyannyira igaz, hogy napjainkban a homoki gyepekkel borított homokbuckákon jelentős energiabefektetés mellett, mechanikus vegetációeltávolítással tudják csak fenntartani a bemutatási célra szolgáló egy-két mozgó homokbuckát a Kiskunsági Nemzeti Park munkatársai. Mindez jól mutatja, hogy alapvetően a túl intenzív legeltetés felhagyása járult hozzá a homokmozgások megállításához.

Az 1970-es évektől kezdve egy újabb ökológiai probléma merült fel: a régió kiszáradása, mely a talajvíz szintjének drasztikus, máig tartó csökkenésében követhető nyomon (Szilágyi és Vorosmarty 1997, http1). A homokmozgások viszonylag egyszerúen magyarázható mechanizmusával és sikertörténetnek tekinthető megoldásával ellentétben a szárazodás jóval összetettebb probléma, melynek számos, egymástól független vagy éppen egymással szorosan összefonódó okát feltételezik. A probléma több mint fél évszázada fennáll, de még jelenleg sincs konszenzus az érintett csoportok között, s így nem is történhetett érdemi lépés a megoldásra. A legellentmondásosabb hatótényező maga a homokfásítás, melynek kritikai vizsgálata a homok megkötésében elért sikerek és az utóbbi évek globális lendületet kapott klímavédelmi fásítási kampányai (pl. Bastin et al. 2019, Holl és Brancalion 2020) miatt „tabunak” számít. Jól illusztrálják az álláspontot Bolla et al. (2014) és Bolla (http2) munkái, melyekben a fásítás talajvízszintre gyakorolt negatív hatásait érdemi ellenérvek nélkül vetik el. Jelen áttekintő tanulmányban ezt a tabut kívánjuk körüljárni, és rávilágítunk a homokfásítás vízgazdálkodási árnyoldalára, majd mindezt felhasználva egy fenntartható, a globális klíma- és biodiverzitás-védelmi törekvéseknek, illetve a régió gazdasági érdekeinek is megfelelő új stratégiai irányt fogalmazunk meg.

\section{Talajvízszint-csökkenés a homokhátságon}

A homoktalajokra jellemző a gyenge víztartóképesség (Rawls et al. 1991), azaz a kötöttebb talajokhoz képest a hulló csapadék gyorsabban le tud jutni a mélyebb zónákba, akár a talajvízig, mielőtt a növényzet felhasználná, vagy passzívan elpárologna a legfelsőbb rétegekböl. Ennek következtében a Duna-Tisza közi homokhátságon a magasabb térszínek beszivárgási zónák voltak, míg a mélyebb területeken több térléptékben is feláramlással találkozhattunk. A buckaközök lokális 
többletvízhatásnak kitett környezete kis kiterjedésủ serevényfüzes és kékperjés élőhelyeket tartott fenn (Molnár 2003). A nagyobb deflációs mélyedések kiterjedtebb üde, vizes vagy vízi élőhelyeket alkottak (pl. a fülöpházi Kondor-tó). A talajvízáramlások végül a hátság pereme felé terelték a nedvességet (Mádl-Szőnyi és Tóth 2009). A nyugati perem mentén egy összefüggő lápvidék, a Turján-vidék és az Örjeg alakult ki, míg a keleti és déli végeken diffúzabb vagy foltszerủ elrendeződést mutató vizes élőhelyek jöttek létre, mint pl. a Dél-Kiskunság semlyékei (Molnár 2003, Ladányi et al. 2015). Az áramló talajvíz kapcsolatban áll a mélyebb talajrétegek vízbázisával is, dinamikája így a rétegvizekétől sem független (Erdélyi 1979).

A homokhátság áramló talajvize fontos szerepet tölt be a tágabb régió élőhelyeinek és mezőgazdasági termelékenységének fenntartásában. Az 1970-es évek során azonban a talajvízszint drasztikus csökkenését kezdték el észlelni, és az 1990-es évekre átlagosan 2-4 méterrel csökkent a szintje. A legtöbb nyílt vizü tó kiszáradt, a lápok és egyéb vizes élőhelyek vízutánpótlása megcsappant, és a mezőgazdasági termelékenység is visszaesett (Major és Neppel 1998, Pálfai 1994, 2010, Szilágyi és Vorosmarty 1997). A 2000-es évek elejétől a csökkenés üteme lassulni látszik, de nem állt meg (http1). A legmagasabban fekvő buckavidékeken a 20. század derekán mért alapállapotokhoz képest már a hétméteres csökkenés sem ritka (Ladányi et al. 2010).

Az 1990-es években, amikor a probléma a legfenyegetőbb volt, intenzív kutatás tárgyát képezte a talajvízszint-csökkenés okainak feltárása. A korabeli publikációk összesen öt tényezőt sorakoztattak fel: (1) klimatikus szárazodás, (2) lecsapoló csatornák vízelvezető hatása, (3) talaj- és rétegvíz-kiemelés, (4) a vízzáró rétegek sérülései szénhidrogénforrások után történő próbafúrások során és a (5) homokfásítás (Pálfai 1994). Említésre került még a folyószabályozások hosszú távú hatása is (hullámtérbe szorítás és a meder bevágódása), azonban a homokhátság több tíz méterrel a folyók felett helyezkedik el, és a folyók menti, már a hátságon kívül eső sík területeken alig csökkent a talajvíz szintje (Major és Neppel 1988), így ennek a tényezőnek a hatása nem tủnik megalapozottnak.

A felsorolt tényezők hozzájárulása nehezen, elsősorban közvetett mérési adatokból becsülhetö, és egymástól nem is tekinthetők függetlennek. A csökkenésben betöltött részesedések becslésével ennek ellenére több szerző is próbálkozott. Mivel a homokhátság egyetlen beérkező nedvesség-utánpótlása a hulló csapadék, az 1970-es évektől az 1990-es évekig tartó aszályosabb periódus hatása vitathatatlan; Pálfai (1994) ezt tekinti a legfontosabb tényezőnek. Jelentőségét azonban feltehetően túlbecslik. A hátság mellett elhelyezkedő Solti-síkságon például alig csökkent a talajvíz szintje, noha e fátlan terület időjárása nem különbözött a hátságétól a kérdéses évtizedekben (Major és Neppel, 1998). A csökkenésben tehát az egyéb tényezők is meghatározó szerepet kell, hogy játsszanak. 
A Duna-Tisza közi homokhátságot keresztül-kasul szövik a 20. század közepén és második felében létesített vízelvezető csatornák, melyeket a mélyebben fekvő, folyamatos vagy időszakos vízborításnak kitett területek lecsapolására létesítettek (Ujházy és Biró 2018). Feladatukat el is végezték, ennek ellenére jelentőségüket többen kétségbe vonják a regionális talajvízszint-csökkenés kapcsán. Major (1994) például egyetlen csatorna, a Fehértó-Majsai fócsatorna vízhozamából következtet arra, hogy a csatornák csak medrük megközelítőleg 1 km-es körzetében szárítanak, így minimális a hatásuk. Érdemes azonban még néhány szempontot figyelembe venni: A régió talajvízmozgásai az áramlást fokozó csatornamedrek nélkül is több tíz kilométeres távolságokat hidalnak át, illetve a talajban a víz védve van az evapotranszspirációval szemben, de a csatornákba szivárogva ki van téve a mocsári vegetáció és a légkör szárító hatásának. Ezeket is figyelembe véve a csatornák szerepe aligha lehetett elhanyagolható. Továbbá, ha elfogadjuk az egy km-es hatászónát, a Duna-Tisza közén található összesen 5000 km hosszúságú csatornahálózat (lásd Tölgyesi et al. 2020a), nagyjából 5000 km²-es terület talajvizét apasztja, azaz így is a régió igen jelentős hányadát érinti. Mindazonáltal, a talajvízszint mára számos homokhátsági csatorna medrének a szintje alá süllyedt, így talajvízszint-csökkentő szerepük a 20. század második felében tapasztalthoz képest vélhetően mérséklődő tendenciát mutat.

Az öntözési és kommunális célra történő talaj- és rétegvíz-kiemelések szerepét többen hangsúlyozzák. Szilágyi és Vorosmarty (1997) modellje szerint e tényező járult hozzá legnagyobb mértékben a talajvízszint-csökkenéshez, azonban kérdéses, hogy mennyire tekinthető elsődleges tényezőnek. A korábbi vizes és vízi élöhelyek mellett számtalan közepesen mély fekvésü, üde élőhelyet is fenntartott a talajvíz, melyek a térség mezőgazdasági müvelésre legalkalmasabb területei voltak a sem túl száraz, sem túl nedves viszonyok miatt. A talajvízszint-csökkenéssel értelemszerűen a gyökérzóna nedvességtartalma is csökkent, növelve az öntözés szükségességét, tovább csökkentve a talajvízszintet, mely végül egy negatív spirált generálhat. A talajvízszint és az öntözés így korrelálhat, de nem feltétlenül áll fenn kizárólagos ok-okozati összefüggés, hiszen egyéb szárító tényezők nélkül kevesebb lenne az öntözés is. Az öntözés közvetlen szerepét számszerüsítô eredményeket érdemes tehát némi fenntartással kezelni.

A szénhidrogén-bányászati próbafúrások szerepe az eddigieknél még bizonytalanabb, a talajvízszint-csökkenésben betöltött szerepét érdemben nem becsülték.

Minden hatótényező közül azonban az erdősítés szerepe a legellentmondásosabb, mivel nem csak a hozzájárulás mértékét vitatják, hanem azt is, hogy egyáltalán van-e szárító hatása, sőt, a korábban tárgyaltakkal szemben napjainkban egyre nagyobb területeket érint, a folyamatban lévő fásítási programok következtében. Tanulmányunkban így a fásítás hatásait járjuk körül részletesen. 


\section{Erdőtelepítések hidrológiai hatásai vízhiányos területeken}

A homokhátsági erdők és faültetvények (a továbbiakban „erdők”) hidrológiai hatásait a hulló csapadék útjának nyomon követésével lehet megérteni. A csapadék egy részét a lombkorona felfogja, mely végül onnan elpárolog. Ezt intercepciós veszteségnek nevezzük. Értéke éves szinten az örökzöldek esetén nagyobb, a lombhullatók esetében azonban csak lombfakadástól lombhullásig érvényesül érdemben, így esetükben kisebb értékkel számolhatunk. Szodfridt (1993) például a fenyők intercepcióját 20\% körülire teszi, míg az akácét 9\%-ra, de Major (1974) becslése alapján a fenyőkre 32\% adódott, a lombos erdőkre (nemcsak akác) pedig $18 \%$. A nagy különbségek elsődleges oka az lehet, hogy az értékek függnek az állománysűrüségtől, a fák korától, fenológiai állapotától és az aktuális esők intenzitásától (Führer 1992, 1994). Az mindenestre látható, hogy az intercepciós veszteség az amúgy is alacsony csapadékmennyiség egy tekintélyes hányadát érinti.

A csapadék egy további frakcióját a lágyszárú szint és az avarréteg fogja fel, mely igen változó a különböző élőhelyeken és erdőtípusokban. Nyílt homoki gyepi területeken értéke a csupasz felszínek nagy aránya és az avarréteg hiánya miatt alacsony, de a dúsabb lágyszárú vegetációval borított területeken nagyobb lehet. A fenyőtelepítésekben a gyakran nudum aljnövényzet szerepe elhanyagolható, azonban a laza tủavar komoly adszorpciós és párologtató felület lehet (Putuhena és Cordery 1996). A lombavar mennyisége csekélyebb az akácosokban, de ott a talaj magas nitrogéntartalma és a késői lombfakadás dús tavaszi lágyszárú szint kialakulását eredményezi (Tölgyesi et al. 2020b), melynek az intercepciója friss állapotban és elszáradva is jelentős lehet. Az erdők lágyszárú szintjének intercepciójával az erdészeti modellek mérési adatok híján kevéssé tudnak számolni, ahogy azt Szodfridt (1993) szóvá is teszi.

Az eddigi hatásokkal ellentétes, hogy a talajfelszínre érkező víz párolgását az árnyékosabb és szélcsendesebb erdei környezet mérsékli, míg a gyorsabban felmelegedő, szárító szeleknek kitett, nyílt élőhelyeken jóval nagyobb lehet a párolgás (Erdős et al. 2018). Mérések szerint a talajba fél méternél mélyebbre beszivárgó víz azonban már nincs kitéve többé a párolgásnak (Liu et al. 2015, Tölgyesi et al. 2020b). Ezzel jól összecseng Magyar (1961) Witsch Rudolf 19. századi feljegyzéseiből vett idézete is, miszerint a „kietlen buckatetőkön is a futóhomoknak csak a legfelső, aránylag vékony rétege száraz, alatta pedig már nedves". A víz mennyiségét innentől, vagy még mielőtt e nedves zónába leérne, a növényzet párologtató hatása (transzspirációja) csökkentheti. Erdeink párologtató kapacitása jóval nagyobb, mint a nyílt gyepeké, mivel nagyobb levélfelülettel rendelkeznek, illetve gyökérzónájuk is vastagabb talajréteget használ (Móricz et al. 2009, Szabó et al. 2012). Erdők esetén a lombkorona párologtatásához természetesen hozzáadódik 
a lágyszárú szinté is, mellyel az erdészeti publikációk szintén nem számolnak, holott különösen akácosok alatt a vegetációs időszak első felében tekintélyes értéket feltételezhetünk (Tölgyesi et al. 2020b). Gyakori elképzelés, hogy a fokozott evapotranszspiráció egyben csapadékszaporító hatású is, s e tulajdonsággal a gyepek nem rendelkeznek. A homokhátsági erdők esetén régión belüli csapadékszaporítással kapcsolatos mérést nem ismerünk, azonban a becslések csupán 3-4\%-ra teszik a mértékét (Szabó et al. 2012). Ez a hatás azonban elméletileg is csak olyan esetben érvényesülhet, ahol a hasznosítatlan víz távozna a rendszerből (pl. fátlan hegy- és domboldalakról lefolyva, folyókba jutva). A homokhátság esetén a buckaközök, deflációs mélyedések és a peremvidék feláramlási zónáinak lágyszárú vegetációja juttatja vissza a légkörbe a magasabb térszíneken beszivárgott csapadékvizet, azaz „nem veszne kárba”. E mechanizmus rámutat egy további problematikus témakörre, a fák hütő hatására (pl. Li et al. 2015, Moss et al. 2019). A hütés a rendelkezésre álló vízmennyiség halmazállapot-változásakor fellépő hőelvonásra, és a kialakuló többletfelhőzet fényvisszaverö hatására vezethető vissza. Annak, hogy a lombkorona vagy a többletvízhatástól függő lágyszárú vegetáció párologtatja-e el ezt a vizet, nincs hatása a hütés mértékére. Amennyiben az erdőtelepítések veszik át a párologtató funkciót, azzal csak a hatás áthelyeződése történik meg. Ha viszont nem a korábban többletvízhatásnak kitett helyeken történik a párolgás, akkor ott a lebomlatlan szerves anyagokban gazdag, gyakran tőzeges talaj kiszáradásával megindul annak oxidációja, mely egyrészt exoterm folyamat, másrészt szén-dioxidot juttat a légkörbe (Friggens et al. 2020). Mindezt tetézi a fásszárú vegetáció, elsősorban a fenyvesek alacsony albedója, mely mérsékli a párolgás hütő hatását vegetációs időszakban, míg télen emelheti is a hőmérsékletet (lásd pl. Luyssaert et al. 2018). Mindezeken felül a lombkorona, szemben a fátlan területekkel, mérsékli az éjszakai lehülést is, gátolva ez által a harmatképződést (Tölgyesi et al. 2018). Végeredményben a teljes homokhátság termikus mérlege csak pozitív irányba tud elmozdulni az erdőborítás növelésével.

A talajvíz csapadékból történő utánpótlását tehát a lombkorona, a lágyszárú szint és az avar intercepciója, a feltalajból történő párolgás, illetve a fák, cserjék és lágyszárúak párologtatása csökkenti, mely együtt az ún. evapotranszspirációt adja. Tekintettel a párologtató felület nagyságára, homoki erdeinkben lényegesen nagyobb evapotranszspirációs értékről beszélhetünk, mint a nyílt területek esetén (Móricz et al. 2009, Szabó et al. 2012). Számos becslés történt a konkrét értékekre, azonban ezek igen bizonytalanok, mivel erősen befolyásolja őket az erdóállomány kora, sürüsége, fafajösszetétele, akárcsak az aktuálisan hozzáférhető vízmennyiség, továbbá a felsorolt összetevőknek nem is szokták mindegyikét figyelembe venni (pl. Szodfridt 1993, Borovics et al. 2020, http2). Gyakran találkozhatunk olyan értékekkel is, melyek alapján e konzervatív becslések nagyobb 
összeget adnak ki az aktuálisan hulló csapadéknál. Ezt tekintjük negatív vízmérlegnek, vagyis olyan esetnek, amikor több vizet párologtatnak el az erdők, mint amennyi beérkezik (2. ábra). Ilyen eredményeket adtak például Major (1974) számításai, melyek szerint az evapotranszspiráció a vizsgált homokhátsági erdőkben meghaladja a csapadékot, de Szabó et al. (2012) és Mátyás et al. (2018) is kiemeli az alföldi erdők negatív vízmérlegét. Az ilyen, ellenmondásosnak tünő eredmény nem számolási mủtermék, hanem a vízhiányos területek fásítása során jelentkező általános jelenség (Soares és Almeida 2001, Farley et al. 2005). Magyarázata az, hogy egyes fafajok közvetlenül elérik a talajvíz által nedvesen tartott mély rétegeket is, és azt a zónát csapolják meg. E hatást egyetlen erdészeti publikáció sem kérdőjelezi meg homoki erdeink kapcsán (pl. Major 1974, Gácsi 1998, Gőbölös 2002). A homokhátsági fafajok közül a nyár és a tölgy számára a talajvíz

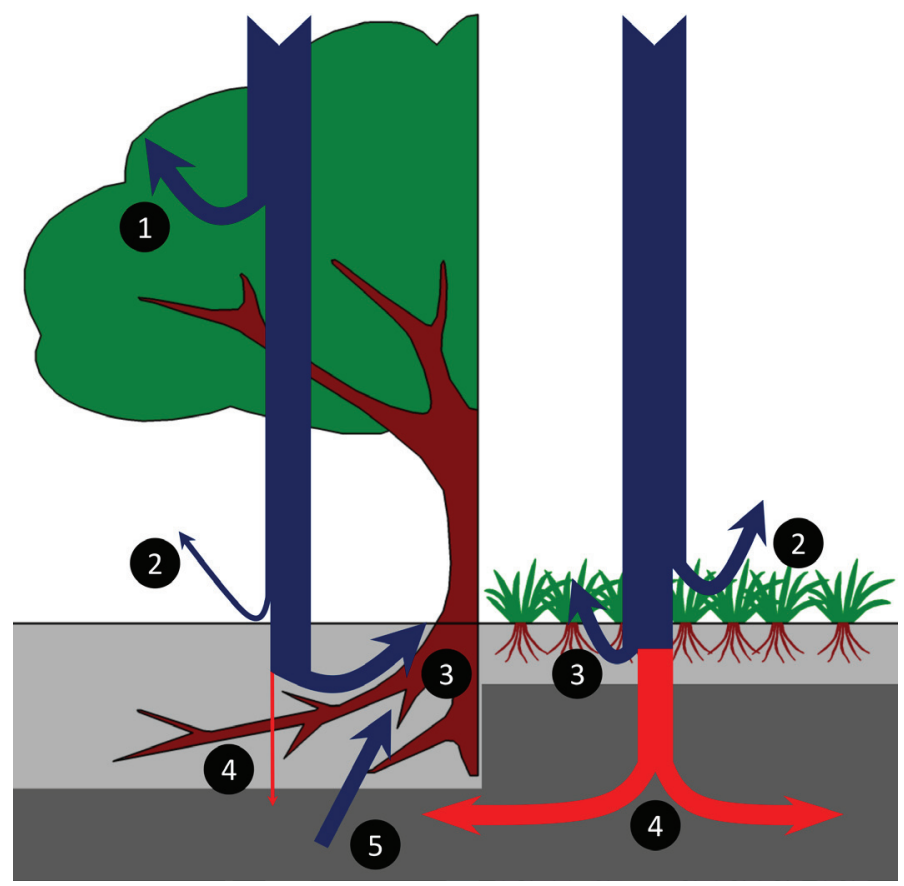

2. ábra. A Duna-Tisza közi homokhátság száraz erdeinek hidrológiai sémája a beérkező csapadék (fentről induló kék nyilak) útjának nyomon követésével. 1: A fák lombkoronájának intercepciója révén a csapadék egy része elpárolog, míg ilyen veszteség a gyepeken nincs. 2: A lágyszárú és avarszint intercepciója, illetve a talaj párolgása során is távozik némi nedvesség, melynek összesített értéke az erdőkben feltehetően csekélyebb. 3: A talajba jutott nedvesség egy részét a növényzet felszívja és elpárologtatja. Ennek mennyisége erdők esetén lényegesen nagyobb, mint gyepeken. 4: A talajvízbe leszivárgó vízmennyiség (piros nyilak) erdők esetén minimális, a talajvizet érdemben a gyepeken átszivárgó víz táplálja. 5: Az erdők fái a talajvizet közvetlenül is csapolják, tekintélyes negatív vízmérleget, és a gyepekhez képest alacsonyabb talajvízszintet okozva. Világosszürke színezés: telítetlen talajzóna; sötétszürke: telített talajzóna. 
elengedhetetlen vízforrás, de alkalomadtán az akác is hasznosítja, viszont a fenyő kevésbé szorul rá (Gőbölös 2002). Ugyanakkor a homokhátsági fátlan élőhelyek lágyszárú vegetációja a mélyben található talajvíztől független, azt közvetlenül nem csapolja.

Mindezek önmagukban nehezen adnak okot arra, hogy megkérdőjelezzük az erdők talajvízszint-csökkentő hatását, noha egyes szerzők számításai szerint a hatás nem számottevő. Szodfridt (1994) és Gácsi (2021) szerint sem a gyepek, sem az erdők alatt nincs talajvíz-utántöltődés, így az erdők sem szárítanak jobban, mint a gyepek. Mivel a talajvíz egyetlen bemenete a homokhátság területén a csapadék (Pálfai 2010), ez nem állja meg a helyét, és mutatja az evapotranszspirációs számítások korlátozott megbízhatóságát, illetve az adatok gyakran nem kellően körültekintő értelmezését. Gácsi (2021) például ott vét elemi hibát, hogy adatai szerint egy év csapadéka nem elég a telítetlen feltalaj teljes átnedvesítésére, $\mathrm{s}$ nem veszi figyelembe, hogy bármely rákövetkező év csapadéka már egy részben átnedvesített talajt fog érni, és nem ,nullázódik” le a talaj nedvességtartalma az év végén. A felhalmozódó nedvesség egy része - legalábbis nyílt területeken - már többletként jelentkezik, és el is érheti a talajvizet, akármilyen mélyen is található az, ahogy azt pl. Major (1974) számításai igazolták is.

Mindazonáltal, a legtöbb adat arra enged következtetni, hogy csak a gyepek alatt van érdemi talajvíz-utántöltődés, az erdők alatt pedig valóban nincs, vagy minimális. Az erdészeti publikációk a vegetációs időn kívüli időszakot tekintik az újratöltődés időszakának (Major 2002), azonban Borovics et al. (2020) ménteleki adatsora a téli talajvízszint-emelkedést nem igazolja, ahogyan Gácsi (2021) adatai is csak az átlagosnál csapadékosabb években valószínüsítettek leszivárgást. Tölgyesi et al. (2020b) alapján az erdők talajának felső 120 cm-es zónája a vegetációs időszakban az eddig elvárhatóak szerint erősen kiszárad, különösen fenyő esetén. Mivel a fenyők gyökerei jelen ismereteink szerint a talajvizet kevéssé érik el, nem is meglepő, hogy a felső réteget maximálisan kihasználni kényszerülnek. A fenyő esetén még ennek a $120 \mathrm{~cm}$-es zónának a stabil vízállapotig való feltöltődése is csak tél végére, egy rövid periódus erejéig történik meg, majd kora tavasszal ismét csökkenésnek indul a víztartalom. Ezen adatok szerint is valószínűtlen, hogy a több méter mélyen húzódó talajvíz szintjéig számottevő vízmennyiség szivároghat le alattuk.

Az erdők alatt húzódó talajvíz forrása tehát az erdőkön kívül van. A fátlan területekre lehulló csapadék talajvizet elérő frakciója horizontális áramlással juthat be az erdők alá (2. ábra). Nyílt területek magános fái alatt a napszaki talajvízszint-ingadozásokban mindez jól nyomon követhető. Major (2010) mérései alapján nappal a talajvíz szintjében egy „,depressziós tölcsér” alakul ki a fa alatt, míg éjjel ez kiegyenlítődik. A kiegyenlítődés üteme teljes erdőállományok alatt természetesen 
nem lehet ilyen gyors, és csak a vegetációs időszakon kívül mérséklődik (Gácsi 1998). Major (2002) homokhátsági fenyvesek alatt nagyjából 1 m-rel mért alacsonyabb talajvízszintet, mint a környező gyepek alatt, Szodfridt és Faragó (1968) pedig átlagosan 50-60 cm-es süllyedést tapasztalt erdők alatt. A hazainál szélsőségesebb, erősen kontinentális klímájú orosz erdős sztyeppek esetén a különbség viszont akár a nyolc métert is elérheti (Major 2002).

Az itt felsorakoztatott különbségek természetesen alulbecslést adnak a gyepek alatti szinthez viszonyított relatív csökkentő hatásra, hiszen horizontális utántöltődés a vegetációs periódus alatt is lehet, továbbá a csökkenés egyéb okai nem egyenletesen oszlanak meg az erdők és a fátlan területek között. A vízelvezető csatornák a mély fekvésü gyepeken, vizes élőhelyeken át húzódnak (Major 1994), és a vízkiemelések is leginkább a fátlan területekhez kötödnek. Ebböl kifolyólag az erdők talajvízszint-csökkentő hatását akkor sem vethetnénk el feltétlenül, ha a mostanival ellentétben az erdők alatt magasabban állna a talajvíz szintje.

Egyértelmü százalékos számértéket adni a homokfásítás talajvízszintcsökkenésben betöltött szerepének azonban igen nehéz. Pálfai (1994) egy komplex, többváltozós lineáris egyenlettel modellezte a különféle hatótényezők, azaz a klimatikus szárazodás, csatornázás, vízkiemelés és fásítás részesedését, noha a publikáció elejétől fogva felhívja a figyelmet a becsült paraméterek bizonytalanságára. A modellt lépésről lépésre finomította, hogy minél reálisabb képet adjon, és eközben az erdőborítás és a talajvízszint közötti összefüggést mutató korrelációs koefficiens egyre erősebb lett. A modellegyenletben az erdőborítás együtthatója az összes paraméteré közül a legmagasabb volt, mely azt jelenti, hogy nemcsak szoros az összefüggés a talajvízszint és az erdőborítás között, hanem az erdőborítás növekedése gyorsabb ütemben csökkenti a talajvízszintet, mint a többi változó hasonló arányú növekedése. A legjobb modellt azonban Pálfai végül nem interpretálta, hanem egy konzervatívabb, 10\%-os értéket ad az erdőknek, és csak „földhasználatban bekövetkezett változásokként” utal rájuk.

További elgondolkoztató adat a homokhátság talajvízszintje kapcsán, hogy a csökkenés nem egyenletes, hanem jól követi a táji léptékü erdőborítás mértékét (Major és Neppel 1988). Itt azonban igazat kell adnunk Szodfridt (1993) ellenvetésének, miszerint ez csak korreláció, és önmagában nem tekinthető okokozati összefüggésnek. Figyelembe véve azonban a korábban felsorakoztatott bizonyítékokat, ez az adat is beleillik a képbe, és levonhatjuk a következtetést, hogy a homokfásítás hozzájárult a homokhátság talajvízszintjének csökkenéséhez. A csökkenés legintenzívebb periódusában, a '70-es és '90-es évek során a homokfásítás számos egyéb tényezővel osztozott, így jelentősége nehezen becsülhető. Mára azonban az éves csapadékösszeg visszaállt a '70-es évek elötti értékre, így a növekvő hőmérséklet ellenére is mérsékeltebb a klimatikus vízhi- 
ány. A vízkiemelés intenzitása a 20. században tapasztalt csúcshoz képest ugyancsak mérséklődött, noha az utóbbi időben ismét növekedés tapasztalható (http1). A belvízelvezető csatornák jelentős része mára funkcióját vesztette (Tölgyesi et al. 2020a), és a szénhidrogénforrások után kutató próbafúrások sem folytatódtak a korábbi ütemben. Mindezekkel szemben az erdőborítás nem csökkent, sőt növekszik, így abszolút értékben vett hatása sem csökken, relatív hatása viszont feltehetően növekszik. Minden további erdőtelepítés a régió szárazodását fokozza.

\section{A homokfásítás jövője}

Globális léptékben egyre intenzívebb fellépést tapasztalhatunk a klíma és a biodiverzitás védelme terén. Jelenleg a legnépszerübb megoldás az erdősítés, mely azon alapul, hogy a fátlan területek beerdősítésével a légköri szenet áthelyezzük a biomasszába. Ennek nyomán indult el a Bonn Challenge globális fásítása, a Trillion Trees kampány, az EU 2030-as biodiverzitási stratégájában megfogalmazott három milliárd fa elültetése, vagy a hazai civilek által indított 10 millió Fa mozgalom. Mindezekkel összhangban az Alföld területén is kiterjedt erdőtelepítések vannak kilátásba helyezve (Gribovszki et al. 2017), melynek legfőbb célterületei a homokhátságok lehetnek. Führer és Járó (2005) egészen pontosan 116300 ha telepítését tervezte a homokhátság rossz termőképességủ szántóinak helyére, mely azonban a jelen tanulmányban bemutatott hidrológiai megfontolások alapján erösen ellenjavallt.

A tervezett erdők valóban jelentős mennyiségü szenet kötnek meg, noha ennek hosszú távú értéke mindig túl van becsülve, lévén a felnövő fákat vágásérettség elérésével kivágják, és egy részüket tüzelőként hasznosítják, de a fennmaradó hányadból készülő faipari termékek széntartalma is csak ideiglenesen vonódik ki a szénkörforgásból. A letermelést követően a visszamaradó holtfa és avar maradéktalanul lebomlik az újratelepítés talajmunkái során (3. ábra). Mindezt tetézi az intenzív erdőgazdálkodás során használt gépek és jármúvek üzemanyag-fogyasztása során kibocsátott szén-dioxid. Tehát mindig csak az átlagos regionális faborításhoz tartozó széntartalommal kalkulálhatunk, az éves szénmegkötési ráta értelmezhetetlen és félrevezető. A korábban ismertetett hidrológiai hatásoknak megfelelöen a szénmegkötés ára a talajvízkészletek megcsappanása (lásd még Jackson et al. 2005). Mivel a hátság talajvizei tartják fenn a mélyen fekvő vizes élőhelyek vízutánpótlását, ennek további csökkenése a kiszáradásukat fokozza. A lápi talajokra a lebomlatlan növényi anyagok szénben gazdag maradványaiból álló tőzeg felhalmozódása jellemző. A lebomlást az oxigénszegény, pangó víz gátolja, lévén a lebomlás aerob folyamat. A vízutánpótlás csökkenésével e tőzeges, szerves anyagokban gazdag talaj kiszárad, szénelnyelőből szénkibocsátóvá válik. 


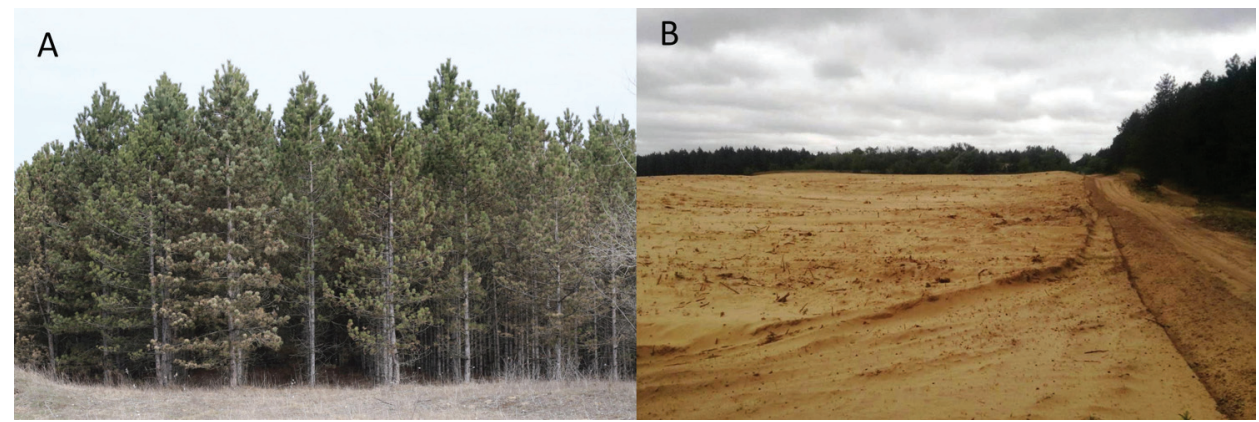

3. ábra. A homokhátsági faültetvények (a) jelentős mennyiségű szenet tartalmaznak biomasszájukban, azonban a letermelést követően (b) ennek jelentős része hosszabb vagy rövidebb távon visszakerül a légkörbe, így nem tekinthetök hatékony szénmegkötőnek (részleteket lásd a szövegben).

Noha Duna-Tisza közi viszonylatban a kiszáradó, széndús talajok szén-dioxid kibocsátását ismereteink szerint eddig nem vizsgálták, globálisan azonban számtalan tanulmány igazolja a jelenséget (pl. Alm et al. 1999, Hirano et al. 2009). A talaj szénmérlegén túl a csökkent vízállapot visszaveti a korábban többletvíztől függő területek produktivitását (Szilágyi és Vorosmarty 1997), így a gazdasági következmények mellett a biomasszában aktuálisan tárolt szén mennyiségének csökkenésére is számíthatunk. A homokhátsági erdők hidrológiai hatásai tehát áttételesen tovább mérséklik a nettó szénmegkötést, így erősen megkérdőjelezhető, hogy a globális fásítási programok céljainak megfelelnek-e.

Tovább rontja a homokfásítás jövőjét, hogy az aktuális klímaprojekciók szerint a 21. század derekára a homokhátság területe szuboptimális lesz a fás vegetáció számára, és inkább sztyeppi klíma válik uralkodóvá, melyen a zárt erdők gazdaságos fenntartása nehezen képzelhető el (Illés és Fonyó 2016, Mátyás et al. 2018). A közeljövőben telepített erdők tehát a vágásértettséget aligha érik meg, s így olyan gazdasági haszonnal sem kecsegtetnek, mely a lokálisan érvényesülni kívánó erdőgazdálkodók számára felülírhatná a környezeti terhelést (vö. Gácsi 2021). A helyzetet tovább súlyosbítja, hogy a szárazodó erdők, különösen a fenyvesek - melyek telepítését újra állami támogatás segíti (http3) - fokozzák a táj tüzveszélyességét a nyári aszályok során, és begyulladást követően jóval pusztítóbb tüzeket várhatunk az esetükben, mint a gyeptüzek kapcsán. A tűzveszélyre hívja fel a figyelmet néhány korábbi hazai tüzeset, illetve a kiterjedt ukrajnai homoki fenyöültetvények tüzei is, melyek során csak 2020-ban 20000 ha esett áldozatul, rövid időn belül fátlan tájjá változtatva a kiterjedt erdőségeket (Brian Milakovsky, szóbeli közlés). A homokfásítás tüzveszélyességet fokozó jövőbeli hatása egészségügyi és anyagi károkkal is fenyeget, de egyben azt is jelenti, hogy a megkötött szén is visszakerül a légkörbe. A vízhiányos élöhelyek klímaváltozás kapcsán fokozódó tüzveszélyessége miatt a bolygó más hasonló régióiban sem ajánlott a 
szénmegkötés céljából történő erdősítés (Dass et al. 2018), így a Duna-Tisza közi homokhátságon sem.

Mindezeket figyelembe véve, a Duna-Tisza közi homokhátságon új erdők telepítése ökológiai, természetvédelmi, környezetvédelmi, egészségügyi, vagyonvédelmi és gazdasági szempontból sem javasolt, és a legszárazabb termőhelyeken a letermelt erdőállományok újratelepítése és erdő mủvelési ágban tartása is átgondolandó. Hosszabb távon a homokhátság erdőborításának csökkentése az egyetlen járható út, melynek során a kiterjedt zárt erdők helyett mezővédő fasorokban, magánhasználatú facsoportokban, agrárerdészeti rendszerekben gondolkozunk, és általánosságban az erdős sztyepp fiziognómiát utánozzuk.

\section{Javasolt tájhasználati irányelvek}

A homokhátság erdőborításának csökkentésével, azaz az üzemtervnek megfelelően letermelt faültetvények újratelepítésének mellőzésével azonban nem szabad elkövetni a korábbi hibákat, így kerülendő a felszabaduló fátlan területek legeltetéses túlhasználata, illetve a túltartott vadállomány, hiszen az a homok újbóli megindulását eredményezné. A felszabaduló területeken az őshonos erdős sztyepp élőhelyek rekonstrukciója javasolható stratégiai szempontból. Az Európai Unió 2030-as biodiverzitási stratégiája összesen 650000 km² szárazföldi élőhely helyreállítását írja elő (COM [2020] 380 EB), mely hazánkban is kiterjedt élőhelyrekonstrukciókat tesz hamarosan szükségessé. Jelentős gazdasági potenciálú területeken az intenzív müvelés felhagyása lokális profitcsökkenéshez vezethet, így restaurációs szempontból kevésbé alkalmas célterületek. A homokhátsági erdők termőhelyeinek gazdasági potenciálja azonban minden szempontból a legalacsonyabbak közé tartozik hazánkban. E területek így a legalkalmasabbak közé tartoznak EU-s kötelezettségünk teljesítéséhez, és az őshonos erdős sztyepp élőhelyek rekonstrukciója a korábban felsorolt minden egyéb szempontból is célszerü lenne a jelenlegi zárt erdők helyén. További, s egyre terjedő területhasználati forma a homokhátságon a napelemparkok telepítése. Alternatívaként a fel nem újítandó erdők helyén megfontolandó ezek támogatása, természetesen természetvédelmi szempontból megfelelően kidolgozott és jogilag szabályozott keretek között. Előfordulhat azonban, hogy a letermelt területek használatát nem lehet elöre ilyen formában megtervezni, vagyis hosszabb ideig parlagon maradnának. Ekkor komoly esély van a bolygatott terület inváziós gócponttá válására (Csecserits et al. 2016), különösen, ha a közvetlen közelben nincsenek öshonos propagulumforrásként szolgáló, jó természetességi állapotú erdős sztyepp foltok. Ilyenkor a hidrológiai 
problémák ellenére is megfontolandó őshonos fafajú felújítást végezni, és idővel lehetővé tenni a természetes felnyílást.

A homokhátsági erdők erősen negatív vízmérlegének elfogadásával új távlatok nyílhatnak meg a fásítási stratégiákban. Ártereink évente egy vagy több alkalommal jelentős többletvizet kapnak. Ezt a vízmennyiséget jelenleg - a gátak közé szorított szük hullámtereket lefolyócsatornaként használva - a lehető leggyorsabban eltávolítjuk az országból. Egy vízhiányos, egyre szárazodó régióban ez komoly pazarlásnak tekinthető, s ezt a vizet célszerü lenne valamilyen módon „hasznosítani”. A kiszámíthatatlan, gyakran villámárvízként érkező víz a szántóföldi müveléssel nehezen összeegyeztethető. A nagy vízigényü fafajokból álló erdők számára azonban nem okoz problémát az időszakos vízborítás. Bár jelenleg a szük hullámtér jelentős erdőborítással bír, az ártér mentett oldalának újra vízjárttá tételével az erdősítési potenciáljuk jelentősen javítható lenne. A már megépített szükségtározók jelenleg többnyire kihasználatlanok, mivel csak a legnagyobb árvizek esetén nyitják meg azokat, $\mathrm{s}$ a területükön a szántóföldi müvelés problematikus. A hullámtérrel létesített folyamatos összeköttetés nagy produktivitású erdők kialakítását tenné lehetővé. E tájhasználati átalakítás „három az egyben” módon járulna hozzá az EU 2030-as biodiverzitási stratégiájában elöírt kötelezettségek teljesítéséhez:

1. Amennyiben sikerül természetközeli telepítéseket létrehozni, hozzájárulnak az élőhely-helyreállítási kötelezettségünk könnyebb teljesítéséhez.

2. A stratégia elöírja $25000 \mathrm{~km}^{2}$ folyó restaurációját is, melyhez így szintén hozzájárulnánk.

3. A stratégia egyik fó akciója továbbá 3 milliárd fa ültetése, melynek az árterek helyenként erdőtelepítési céllal történő megnyitása igencsak megfelelne.

Az EU jelentős pénzügyi hátteret biztosít az előírásoknak való megfeleléshez (jelen tervezetek szerint összesen évi 20 milliárd eurót), így a javasolt változtatásokra a szükséges támogatások hozzáférhetőek lehetnek. A biodiverzitási stratégián túl is számos kedvező hatással számolhatunk a javaslatok megvalósítása esetén:

1. A jelenleg gyakran belvizes vagy elárasztott, mélyártéri szántók (hullámtéri és mentett oldali egyaránt) problémáira azonnali megoldást jelentene.

2. A víz számára hozzáférhető árterek vízbefogadó kapacitásának növelésével az árhullámok magassága drasztikusan csökkenne, és ezzel a vagyonvédelmi kockázat, illetve az árvízvédelmi intézkedések költsége mérséklődne. 
3. A telepített erdők jelentős evapotranszspirációja révén a jelenleg „hasznosítatlanul" elvezetett víz jelentős része a légkörbe jutna, javítva a régió mezoklímáját.

Összefoglalásként tehát elmondhatjuk, hogy a Duna-Tisza köze vízhiányos homoki élőhelyein a homokfásítás a talajvízkészletekre és a tágabb régió hidrológiai viszonyaira igazoltan negatív hatást gyakorol, így a továbbiakban nem lenne szabad támogatni. A talajvízszint csökkenésének legintenzívebb időszakban, a '70-as és '90-es évek között számos szinergista tényezővel együtt hatott, így részarányát nehéz pontosan megállapítani. E tényezők szerepe azonban mára többnyire mérséklődött, a homokfásítás hatása azonban nem csökkent, sőt a tervezett fásítások csak súlyosbítják a problémát. Figyelembe véve a részletesen bemutatott hidrológiai vonatkozásokat, a klímaprojekciókat, a nettó szénmegkötés mérsékelt voltát és egyéb kockázatokat (pl. a tüzveszélyesség növekedése), a társadalom egésze számára kedvezőtlen mindennemü új erdő létesítése a homokhátságon, sőt, a jelenlegi erdőborítás csökkentése indokolt a fent részletezett módon. Ezzel párhuzamosan az alföldi erdőtelepítés súlypontját a nagy folyóink térségébe lenne érdemes áthelyezni, ahol az árterek rekonstrukciójára, kiszélesítésére kiváló lehetőséget biztosítanának, és számos jótékony gazdasági, társadalmi és ökológiai hatásuk lenne lokális és regionális szinten is. Mindezek megvalósításához szorgalmazzuk a különféle tájhasználók, a vízügy, az erdészetek és a döntéshozók közötti hatékony párbeszéd kialakítását, illetve a lokális érdekek és akadályok helyett a végső cél pozitívumainak előtérbe helyezését.

Köszönetnyilvánitás - A publikáció elkészülését az OTKA PD 132131 és FK 134384 számú pályázatok, a Bolyai János Kutatási Ösztöndíj, az ÚNKP Bolyai+ Felsőoktatási Fiatal Oktatói, Kutatói Ösztöndíj, illetve az MTA Lendület Programja támogatta. A szerzők köszönettel tartoznak Bolla Bencének, Szabó Andrásnak, Borovics Attilának és Sipos Ferencnek a kézirat elkészítése során nyújtott javaslataikért.

\section{Irodalomjegyzék}

Alm, J., Schulman, L., Walden, J., Nykänen, H., Martikainen, P. J., Silvola, J. (1999): Carbon balance of a boreal bog during a year with an exceptionally dry summer. Ecology 80: 161-174. https://doi.org/10.1890/0012-9658(1999)080[0161:CBOABB]2.0.CO;2

Bastin, J. F., Finegold, Y., Garcia, C., Mollicone, D., Rezende, M., Routh, D., Zohner, C. M., Crowther, T. W. (2019): The global tree restoration potential. Science 365: 76-79. https://doi. org/10.1126/science.aax0848

Bodrogközy, Gy. (1957): Die Vegetation der Weisspappel-Haine in dem Reservat „Emlékerdő” bei Szeged-Ásotthalom. Acta Biologica Szegediensis 3: 127-140.

Bolla, B., Kalicz, P., Gribovszki, Z. (2014): Erdőállományok vízháztartása a kiskunsági homokhátságon. Erdészettudományi Közlemények 4(2): 21-31. 
Borovics, A., Bolla, B., Szabó, A. (2020): Adalékok a homokhátsági erdőállományok vízháztartásra gyakorolt hatásának helyes megítéléséhez. Erdészeti Lapok 155(9): 260-263.

Csecserits, A., Botta-Dukát, Z., Kröel-Dulay, Gy., Lhotsky, B., Ónódi, G., Rédei, T., Szitár, K., Halassy, M. (2016): Tree plantations are hot-spots of plant invasion in a landscape with heterogeneous land-use. Agriculture, Ecosystems amnd Environment 226: 88-98. https://doi. org/10.1016/j.agee.2016.03.024

Dass, P., Houlton, B. Z., Wang, Y., Warlind, D. (2018) Grasslands may be more reliable carbon sinks than forests in California. Environmental Research Letters 13: 074027. https://doi. org/10.1088/1748-9326/aacb39

Erdélyi, M. (1979): A magyar medence hidrodinamikája. VITUKI, Budapest, 82 p.

Erdős, L., Tölgyesi, Cs., Cseh, V., Tolnay, D., Cserhalmi, D., Körmöczi, L., Gellény, K., Bátori, Z. (2015): Vegetation history, recent dynamics and future prospects of a Hungarian sandy foreststeppe reserve: forest-grassland relations, tree species composition and size-class distribution. Community Ecology 16: 95-105. https://doi.org/10.1556/168.2015.16.1.11

Erdős, L., Ambarl1, D., Anenkhonov, O. A., Bátori, Z., Cserhalmi, D., Kiss, M., Kröel-Dulay, Gy., Liu, H., Magnes, M., Molnár, Zs., Naqinezhad, A., Semenishchenkov, Y. A., Tölgyesi, Cs., Török, P. (2018) The edge of two worlds: A new review and synthesis on Eurasian forest-steppes. Applied Vegetation Science 21: 345-362. https://doi.org/10.1111/avsc.12382

Farley, K. A., Jobbágy, E. G., Jackson, R. B. (2005): Effects of afforestation on water yield: a global synthesis with implications for policy. Global Change Biology 11: 1565-1576. https://doi. org/10.1111/j.1365-2486.2005.01011.x

Friggens, N. L., Hester, A. J., Mitchell, R. J., Parker, T. C., Subke, J.-A., Wookey, P. A. (2020): Tree planting in organic soils does not result in net carbon sequestration on decadal timescales. Global Change Biology 26: 5178-5188. https://doi.org/10.1111/gcb.15229

Führer, E. (1992): Intercepció meghatározása bükk, kocsánytalan tölgy és lucfenyő erdőkben. Vizügyi Közlemények 74(3): 281-294.

Führer, E. (1994): Csapadékmérések bükkös, kocsánytalan tölgyes és lucfenyves ökoszisztémákban. Erdészeti Kutatások 84(1): 11-35.

Führer, E., Járó, Z. (2005): Az erdővagyon bővítése a mezőgazdaságilag gazdaságosan nem hasznosított földterületek beerdősítésével. In: Molnár, S. (szerk.): Erdö-fa hasznositás Magyarországon. Nyugat-Magyarországi Egyetem, Faipari Mérnöki Kar, Sopron, pp. 130-136.

Gácsi, Z. (1998): Adatok az alföldi erdők és a talajvíz kapcsolatához III. Erdészeti Lapok 133(5): $158-159$.

Gácsi, Z. (2021): Moszkvában Mercedeseket osztogatnak! Erdészeti Lapok 156(1): 10-11.

Gaskó, B. (2009): Csongrád megye természetes és természetközeli élöhelyeinek védelméről II. Studia Naturalia 5: 5-486.

Gribovszki, Z., Kalicz, P., Balog, K., Szabó, A., Tóth, T., Csáfordi, P., Metwaly, M., Szalai, S. (2017): Groundwater uptake of different surface cover and its consequences in great Hungarian plain. Ecological Processes 6: 39. https://doi.org/10.1186/s13717-017-0106-4

Gőbölös, A. (2002): A „vízhiányos” erdőgazdálkodás kérdései a Duna-Tisza közi homokháton. $H i$ drológiai Közlöny 82(6): 324-326.

Haraszty, L. (2013): Értékörzö gazdálkodás Natura 2000 területeken. ProVértes Természetvédelmi Közalapítvány, Csákvár, 94 p.

Hirano, T., Jauhiainen, J., Inoue, T., Takahashi, H. (2009): Controls on the carbon balance of tropical peatlands. Ecosystems 12: 873-887. https://doi.org/10.1007/s10021-008-9209-1

Holl, K. D., Brancalion, P. H. S. (2020): Tree planting is not a simple solution. Science 368: 580581. https://doi.org/10.1126/science.aba8232 
Illés, G., Fonyó, T. (2016): A klímaváltozás fatermésre gyakorolt várható hatásának becslése az AGRATéR projektben. Erdészettudományi Közlemények 6(1): 25-34. https://doi.org/10.17164/ EK.2016.003

Jackson, R. B., Jobbágy, E. G., Avissar, R., Roy, S. B., Barrett, D. J., Cook, C. W., Farley, K. A., le Maitre, D. C., McCarl, B. A., Murray, B. C. (2005): Trading water for carbon with biological carbon sequestration. Science 310: 19-47. https://doi.org/ 10.1126/science.1119282

Kovács, G. (1984): Az ásványi nyersanyagtermelés hatása a felszíni és felszínalatti vizekre. Időjárás 88(5-6): 345-358.

Ladányi, Zs., Deák, Á., Rakonczai, J. (2010): The effect of aridification on dry and wet habitats of Illancs microregion, SW Great Hungarian Plain, Hungary. Landscape and Environment 4: 11-22.

Ladányi, Zs., Blanka, V., Meyer, B., Mezősi, G., Rakonczai, J. (2015): Multi-indicator sensitivity analysis of climate change effects on landscapes in the Kiskunság National Park, Hungary. Ecological Indicators 58: 8-20. https://doi.org/10.1016/j.ecolind.2015.05.024

Li, Y., Zhao, M., Motesharrei, S., Mu, Q., Kalnay, E., Li, S. (2015): Local cooling and warming effects of forests based on satellite observations. Nature Communications 6: 6603. https://doi. org/10.1038/ncomms7603

Lyssaert, S., Marie, G., Valade, A., Chen, Y.-Y., Njakou, D. S., Ryder, J., Otto, J., Naudts, K., Lansø, A. S., Ghattas, J., McGrath M. J. (2018): Trade-offs in using European forests to meet climate objectives. Nature 572: 259-262. https://doi.org/10.1038/s41586-018-0577-1

Mádl-Szőnyi, J., Tóth, J. (2009): A hydrogeological type section for the Duna-Tisza Interfluve, Hungary. Hydrogeology Journal 17: 961-980. https://doi.org/10.1007/s10040-008-0421-z

Magyar, P. (1961): Alföldfásitás, II. kötet. Akadémiai kiadó, Budapest, 622 p.

Major, P. (1974): Síkvidéki erdők hatásának vizsgálata a talajvízpárolgás és tényleges beszivárgás folyamataira. Hidrológiai Közlöny 6: 281-288.

Major, P., Neppel, I. (1988): A Duna-Tisza közi talajvízszint-süllyedések. Vízügyi Közlemények 70(4): 605-626.

Major, P. (1994): A Duna-Tisza közi hátsági terület lefolyási viszonyainak, talajvízkitermelésének és a talajvízben történő szikkasztásnak hatása a talajvízszint változására. In: Pálfai, I. (szerk.): A Duna-Tisza közi hátság vízgazdálkodási problémái. A Nagyalföld Alapítvány Kötetei, Békéscsaba, pp. 103-109.

Major, P. (2002): Síkvidéki erdők hatása a vízháztartásra. Hidrológiai Közlöny 82(6): 319-323.

Mátyás, Cs., Berkim I., Bidló, A., Csóka, Gy., Czimber, K., Führer, E., Gálos, B., Gribovszki, Z., Illés, G., Hirka, A., Somogyi, Z. (2018): Sustainability of forest cover under climate change on the temperate-continental xeric limits. Forests 9: 489. https://doi.org/10.3390/f9080489

Molnár, Zs. (2003): A Kiskunság száraz homoki növényzete. TermészetBúVÁR Alapítvány Kiadó, Budapest. 159 p.

Móricz, N., Gálos, B., Gribovszki, Z. (2009): Az erdők intercepciójának mérési és modellezési lehetőségei. Hidrológiai Közlöny 89(4): 35-45.

Moss, J. L., Doick, K. J., Smith, S., Shahrestani, M. (2019) Influence of evaporative cooling by urban forests on cooling demand in cities. Urban Forestry and Urban Greening 37: 65-73. https:// doi.org/10.1016/j.ufug.2018.07.023

Pálfai, I. (1994): Összefoglaló tanulmány a Duna-Tisza közi talajvízszintsüllyedés okairól és a vízhiányos helyzet javításának lehetőségeiről. In: Pálfai, I. (szerk.): A Duna-Tisza közi hátság vízgazdálkodási problémái. A Nagyalföld Alapítvány Kötetei, Békéscsaba, pp. 111-126.

Pálfai, I. (2010): A Duna-Tisza közi hátság vízháztartási sajátosságai. Hidrológiai Közlöny 90(1): 40-44.

Putuhena, W. M., Cordery, I. (1996): Estimation of interception capacity of the forest floor. Journal of Hydrology 180: 283-299. https://doi.org/10.1016/0022-1694(95)02883-8 
Rawls, W. J., Gish, T. J., Brakensiek, D. L. (1991): Estimating soil water retention from soil physical properties and characteristics. In: Stewart, B. A. (ed.): Advances in Soil Science, Volume 16. Springer-Verlag, New York, pp. 213-234.

Soaresa, J. V., Almeida, A. C. (2001): Modeling the water balance and soil water fluxes in a fast growing Eucalyptus plantation in Brazil. Journal of Hydrology 253: 130-147. https://doi. org/10.1016/S0022-1694(01)00477-2

Szabó, A., Kiss, K., Gribovszki, Z., Tóth, T. (2012): Erdők hatása a talaj és altalaj sóforgalmára, valamint a talajvíz szintjére. Agrokémia és Talajtan 61: 195-209.

Szilágyi, J., Vorosmarty, C. (1997): Modelling unconfied aquifer level reductions in the area between the Danube and Tisza rivers in Hungary. Journal of Hydrology and Hydromechanics 45: $328-347$.

Szilágyi, J., Kovács, Á., Józsa, J. (2012): Remote-sensing based groundwater recharge estimates in the Danube-Tisza sand plateau region of Hungary. Journal of Hydrology and Hydromechanics 60: 64-72. https://doi.org/10.2478/v10098-012-0006-3

Szodfridt, I., Faragó, S. (1968): Talajvíz és vegetáció kapcsolata a Duna-Tisza köze homokterületén. Botanikai Közlemények 55(1): 69-75.

Szodfridt, I. (1994): Az erdők és a talajvíz kapcsolata a Duna-Tisza közi homokhátságon. In: Pálfai, I. (szerk.): A Duna-Tisza közi hátság vízgazdálkodási problémái. A Nagyalföld Alapítvány Kötetei, Békéscsaba, pp. 59-66.

Tölgyesi, Cs, Valkó, O., Deák, B., Kelemen, A., Bragina, T. M., Gallé, R., Erdős, L., Bátori, Z. (2018): Tree-herb co-existence and community assembly in natural forest-steppe transitions. Plant Ecology and Diversity 11: 465-477. https://doi.org/10.1080/17550874.2018.1544674

Tölgyesi, Cs., Torma, A., Bátori, Z., Seat, J., Popovic, M., Gallé, R., Gallé-Szpisjak, N., Erdős, L., Vinkó, T., Kelemen, A., Török, P. (2020a): Turning old foes into new allies - harnessing drainage canals for biodiversity conservation in desiccated novel ecosystems. Journal of Applied Ecology, in press. https://doi.org/10.1111/1365-2664.14030

Tölgyesi, Cs., Török, P., Hábenczyus, A. A., Bátori, Z., Valkó, O., Deák, B., Tóthmérész, B., Erdős, L., Kelemen, A. (2020b): Underground deserts below fertility islands? - Woody species desiccate lower soil layers in sandy drylands. Ecography, 43: 1-12, https://doi. org/10.1101/2020.01.20.912220

Ujházy, N., Biró, M. (2018): The 'Cursed Channel': utopian and dystopian imaginations of landscape transformation in twentieth-century Hungary. Journal of Historical Geography 61: 1-13. https://doi.org/10.1016/j.jhg.2018.01.001

\section{Internetes források:}

http1: Keresztesy, A., Nagy, T. (2019): A Duna-Tisza-közi Hátság talajvízkészletére vonatkozó mennyiségi problémák okainak aktualizált vizsgálata. In: A Magyar Hidrológiai Társaság XXXVII. Országos vándorgyülése. Pécs. http://hidrologia.hu/vandorgyules/37/word/0105_keresztesy_attila.pdf (Letöltés időpontja: 2021. 03.21.)

http2: Bolla, B. (2020): Erdőállományok vízháztartása. http://klima.erti.hu/home/erdoallomanyokvizhaztartasa (Letöltés időpontja: 2021. 03. 21.)

http3: FATÁJ (2021): Még több forrás az erdőtelepítések támogatására. https://fataj.hu/2021/08/ meg-tobb-forras-az-erdotelepitesek-tamogatasara/?fbclid=IwAR3JKm6MDLvy jmAcZ3gSFeKhOSGVyMVGuXb5eMjwzPsw6aK7rH7GmmkplU (Letöltés időpontja: 2021. 08. 30.)

\section{Hivatkozott jogszabályok:}

COM(2020) 380 EB rendelet. EU Biodiversity Strategy for 2030 - Bringing nature back into our lives. 


\section{The end of afforestation on dry sand habitats and its dawn on floodplains}

\section{Csaba Tölgyesi ${ }^{1,2 *}$, Zoltán Bátori ${ }^{1}$, Balázs Deák³ ${ }^{3}$ László Erdős ${ }^{2,4}$, Alida Anna Hábenczyus ${ }^{1}$, Luca Kukla ${ }^{1}$, Péter Török ${ }^{2,5}$, Orsolya Valkó ${ }^{3} \&$ András Kelemen ${ }^{5,6}$}

${ }^{1}$ University of Szeged, Department of Ecology, H-6726 Szeged, Közép fasor 52, Hungary

${ }^{2}$ MTA-DE Lendület Functional and Restoration Ecology Research Group, H-4010 Debrecen, Egyetem tér 1, Hungary

${ }^{3}$ Centre for Ecological Research, Institute of Ecology and Botany, Lendület Seed Ecology

Research Group, H-2163 Vácrátót, Alkotmány u. 2-4, Hungary

${ }^{4}$ Centre for Ecological Research, Institute of Ecology and Botany, Experimental Vegetation Ecology Research Group, H-2163 Vácrátót, Alkotmány u. 2-4, Hungary

${ }^{5}$ University of Debrecen, Department of Ecology, H-4010 Debrecen, Egyetem tér 1, Hungary

${ }^{6}$ Horizont Nature Conservation and Scientific Association, H-4032 Debrecen, Hollós $u$. 8, Hungary

*E-mail: festuca7@yahoo.com

The Danube-Tisza Interfluve of Hungary has been experiencing aridification since the 1970s, threatening the existence water-based habitats and the productivity of the region. Numerous factors have been identified that contribute to the process, but there is no consensus on their relative importance. The most contradictory factor is afforestation, which is often considered as a success story for stabilizing moving sand in the region. Here we provide a critical overview of the hydrologic effects of these forests and show that they create a significant negative water balance, accelerating aridification. Other contributing factors are decreasing in importance, while the relative share of afforestation is increasing. We conclude that afforestation should be stopped in the region and the overall forest cover should be decreased by avoiding replantation after clearcutting plantation forests. Afforestation should focus on major river valleys, where it could facilitate the restoration of the floodplains.

Keywords: afforestation, aridification, Danube-Tisza Sand Ridge, forest-steppe, groundwater decline, Kiskunság, regional water balance, tree plantation 